\title{
QUALITATIVE AND QUANTITATIVE APPROACHES TO ACTION RESEARCH
}

\author{
Kusumarasdyati \\ Universitas Negeri Surabaya, kusumarasdyati@unesa.ac.id
}

\begin{abstract}
ABSTRAK
Action research atau penelitian tindakan kelas (PTK) merupakan upaya para pendidik yang reflektif untuk meningkatkan kualitas pengajarannya sehingga hasil pembelajaran siswa juga semakin baik. Pada awal perkembangannya di Amerika Serikat di awal abad 20, PTK menggunakan pendekatan kualitatif. Namun seiring berjalannya waktu, masalah di bidang pendidikan dan pengajaran juga semakin kompleks sehingga beberapa pendidik mulai menggunakan pendekatan kuantitatif. Makalah ini bertujuan untuk memaparkan PTK dengan pendekatan kualitatif dan kuantitatif, disertai dengan contoh-contoh PTK di bidang pengajaran Bahasa Inggris sebagai bahasa asing untuk memperkuat alasan penggunaan masing-masing pendekatan tersebut. Pendekatan apa pun yang digunakankualitatif atau kuantitatif-bukan menjadi masalah dan masih dapat disebut sebagai PTK, asalkan tujuan penelitian tersebut dapat dicapai, yaitu peningkatan kualitas pengajaran.
\end{abstract}

Kata Kunci: penelitian tindakan kelas, pengajaran, bahasa Inggris, bahasa asing

\section{INTRODUCTION}

Teachers have benefited from the use of action research in their classrooms when they realize that some parts of the teaching do not work well and take necessary steps to overcome them. This type of research, which most teachers conduct on daily basis in the classrooms, may not be research in pure sense to generate or to test a theory; rather, it is a form of investigation that can assist teachers to make the teaching and learning process more effective. Action research can be defined as "inquiry teachers undertake to understand and improve their own practice" (McCutcheon \& Jung, 1990:144). In other words, teachers examine the way they teach and make attempts to do it better to promote effective learning (Jones, Kaufman \& Rudd, 2004). Compiling several definitions of action research proposed by a number of experts, Costello (2003:5) listed the following characteristics that those definitions have in common: (1) It is referred to as a term, process, enquiry, approach, flexible spiral process and as cyclic, (2) It has a practical, problem-solving emphasis, (3) It is carried out by individuals, professionals and 
educators, (4) It involves research, systematic, critical reflection and action, (5) It aims to improve educational practice, (6) Action is undertaken to understand, evaluate and change, (7) research involves gathering and interpreting data, often on an aspect of teaching and learning, and (8) Critical reflection involves reviewing actions undertaken and planning future actions.

The history of action research began in the US in the 1930s when Kurt Lewin introduced it as a form of qualitative inquiry in the applied social science, and two decades later it gained momentum in the field of education (Adelman, 1993; Whitehead $\&$ McNiff, 2006). Despite its reliance on the interpretive paradigm at the early stage of development, in the course of time action research was approached using alternative paradigms (McCutcheon \& Jung, 1990). This paper examines action research conducted using different paradigms, limiting them only to two contrasting ones, namely interpretive and positivist. Action research with interpretative paradigm is qualitative in nature, whereas positivism results in quantitative action research. The former will be taken up in the next section, followed by the later.

Qualitative Approach to Action Research

Action research requires teachers to understand their own practice by being selfreflective and examining it critically and systematically (Burns, 2010), paving the way for them to find some aspects of their practice that may need improvement. Such in-depth understanding could be accomplished with optimum results by conducting action research with qualitative approach. Interpretive paradigm, which underlies certain types of qualitative research, views education as a process and school as a lived experience, so understanding the aforementioned process and experience should be carried out deductively by collecting data in order to generate hypotheses rather than testing them. In addition, multiple reality exists as the voices of the researchers and the participants are acknowledged and considered valuable; yet, they are interpreted holistically to make up meaning (Merriam, 1998). This underlying paradigm enables teachers to delve deeply into the teaching and learning process by asking the following questions: "What and how shall we learn and teach? Why is it worth doing? Why must we do it?" (McCutcheon \& Jung, 1990).

An example of action research approached qualitatively was the attempt of an American teacher at a college in Japan to solve a problem occurring in an English class, where the sophomores tended to be silent during the lessons (Snell, 1999). Even when the 
teacher asked questions, the learners were reluctant to answer. The root of the problem turned out to be the Japanese culture, in which students were expected to be quiet, listen to the teacher and refrain from asking questions to respect the teacher. To improve this situation, he gave the learners an authentic material in the form of a text about how students in English-speaking countries actively participated in the classrooms by asking questions or expressing opinions because it was considered culturally appropriate there. Then the teacher explicitly pointed out that he would like the Japanese students to be more active in the classroom, and even frequently mentioned the cultural issues in the text to remind them whenever they were silent. While abrupt change on the part of the learners might not be possible, the teacher found a significant improvement when the learners began to have the courage to ask questions or used gestures (nodding or shaking their head) to respond to the teacher's questions instead of saying nothing. Obviously this action research has answered the questions "how" and "why": he taught English by embedding the cultural issues in the material because the learners' native culture hindered effective communication in the classroom.

Another instance was the research conducted by Stephens et al (2012) who wished to improve the speaking ability of high school students in Chile. They used a project called Film Circle as a scaffold for speaking activities in which the students worked in groups and each member was assigned a particular role in the group work. This intervention involved watching a movie and learning activities were done in three stages: previewing, while-viewing and postviewing. Analysis of qualitative data collected from worksheets, the students' reflection and the teacher's observation resulted in positive outcomes in that the students could think critically, express their ideas better and become more independent learners.

The last study to exemplify action research that employed qualitative approach was conducted by Nunan (2002), who found the freshmen in the University of Hong Kong expected the teacher to transfer most of the knowledge they had to learn as their teachers did in high school. Aiming to improve the freshmen's autonomy in learning English, the study was conducted for one semester by providing them opportunities to self-monitor, self-evaluate and develop appropriate learning strategies. These freshmen had to complete a guided journal at the beginning of the semester, followed by several tasks that were administered in different sessions afterwards. The journal and the tasks became tools to help them increase the awareness of their own cognitive processes while learning English and their attitude toward this language. At the end of the semester, the 306 | E-ISSN: 2527-8754 http:// journal.unesa.ac.id/index.php/Paramasastra 
strategy training could bring positive impacts on the freshmen as they no longer expected spoon-feeding of knowledge from the teacher and could make good use of their potentials in learning English.

Even though some teachers find the qualitative approach beneficial to help them improve their practice through action research, some others think that the quantitative approach could be equally useful. The next section will review the characteristics of quantitative action research and support it with some examples.

Quantitative Approach to Action Research

The quantitative approach stems from positivism, the underlying principles of which considerably differ from those of interpretivism above. According to the positivist stance, education and school are objects or phenomena that can be investigated, and understanding these objects or phenomena should be done deductively by using scientific or experimental research to obtain objective, quantifiable outcomes. Therefore, in positivism reality is considered as stable, observable and measurable (Merriam, 1998). Such views affect the nature of action research teachers conduct in their classrooms. They rely on numerical data obtained from the learners to answer research questions formulated in the following ways: Which technique/media/activity works more effectively for a particular group of learners? What is the correlation between $\mathrm{X}$ and $\mathrm{Y}$ ? How well does a particular strategy help the students learn?

The article "Classroom Action Research: The Teacher as Researcher" (1989) stated that teachers actually do action research once they try to determine what is better or the best for teaching and learning on a daily basis. It also considers that action research is conducted already when teachers attempt to experiment with one group of students and select another group in the same class as the control one to find out whether something is effective or not. Occasionally, the teachers use one group rather than assigning the class into two groups, and administer a pretest and a posttest to obtain information about the effectiveness (Bielska, 2011). To illustrate, Mountford (2007) attempted to solve the problem of reading fluency faced by ten $4^{\text {th }}$ and $5^{\text {th }}$ graders with learning disabilities by using Readers' Theater, in which the learners read a script aloud with appropriate expressions before an audience. She used three research instruments: a student survey to elicit their attitudes toward reading, a 4-point rubric to evaluate their reading performance, and an oral one-minute timed reading to find out the number of words they read per minute. All of the instruments were administered to the participants before and 
after the interventions so she obtained two sets of numeric data from each and labeled them 'pretest' and posttest.' In general, there was an increase when the results of the pretest were compared to that of the posttest, and the gain led to a conclusion that Readers' Theater was an effective technique to overcome reading fluency faced by the $4^{\text {th }}$ and $5^{\text {th }}$ graders.

In a similar vein, Kieltyka (2005) compared different conditions in the interventions when conducting action research to determine which one was the most effective to improve her students' reading comprehension, fluency and attitude toward reading. She utilized a teaching technique called Round Robin Reading, in which the learners took turns reading an unfamilar text aloud in front of an audience, and applied four different conditions to different groups selected randomly from the $4^{\text {th }}$ grade class she taught: no pre-reading discussion without rehearsal time, pre-reading discussion without rehearsal time, no pre-reading discussion with rehearsal time, and pre-reading discussion with rehearsal time. She used oral reading trial as the instrument to measure the students' reading comprehension and fluency, and administered a questionnaire to obtain data about their attitude towards reading, yielding numeric data from both instruments. The results indicated that of four types of reading trials the most effective one turned out to be pre-reading discussion with rehearsal time, and the number of learners who lacked interest in using Round Robin Reading kept dwindling, reaching zero at the end of the intervention. Consequently, this technique was deemed very helpful in enhancing fluency and comprehension of the $4^{\text {th }}$ graders as well as positively shifting their attitude toward reading.

It is essential to distinguish action research which makes use of an experimental design like the above from the experimental research as a scientific inquiry in pure sense. Action research — regardless of the designs it adopts-invariably aims to take a critical, reflective look at the teachers' own practice and improve it. Experimental research, on the other hand, is conducted to test a particular theory and find out whether a component of the theory is effective or not, reporting the results as they are without having improvement as an end. Additionally, the findings of action research apply only to the specific group of learners who participate in it because it attempts to solve a problem faced by these learners, but the findings obtained from a small group of learners (i.e. the sample) in experimental research can be generalized to a larger group (i.e. the population). 
Although the experimental design could be handy to measure improvement in action research, some other studies describe the increase in numerical data in another way. Ely1ldirım (2012), for instance, decided to do action research in two speaking classes she taught in the English Department of Attatürk University in Turkey after she found out that most of the undergraduates there had negative attitudes toward learning English as a foreign language. Being cognizant that the negative attitudes would lead to low motivation and be counterproductive for learning, she performed an intervention for one semester. Instead of using a pretest and posttest to check how much the learners made progress, she had them take an achievement exam several weeks after the course began and another achievement exam at the end of the course. She reported a sharp decrease in the rate of failure in these two classes, from $73 \%$ and $25 \%$ respectively to $3 \%$ and $0 \%$. To detect any change in their attitude, she used a survey containing several items with 5point Likert scale expressing agreement (a score of 5) or disagreement (a score of 1), and the results were presented in the form percentages, most of which indicated positive attitudes after the intervention.

\section{CONCLUSION}

It is evident that action research plays a vital role in promoting better teaching and learning process in the classroom. In expending efforts to improve their practice, some teachers may find it more relevant to approach their action research qualitatively because they need in-depth understanding to overcome the problems. By contrast, some others consider it more appropriate to solve the problems by relying on the quantitative approach and obtain precise, numeric results. The proverb "All roads lead to Rome" may be the best analogy to describe this phenomenon: reflective teachers could adopt qualitative or quantitative approach for the action research they carry out, and regardless of the approach they select they will reach the same goal, namely, the betterment of their own practice.

\section{REFERENCES}

Adelman, C. (1993). Kurt Lewin and the Origins of Action Research. Educational Action Research, 1(1), 7-24.

Bielska, J. (2011). The Experimental Method in Action Research. In D. Gabryś-Barker 
(Ed.), Action research in Teacher Development: An Overview of Research Methodology (pp. 85-120). Katowice: Wydawnictwo Uniwersytetu Śląskiego.

Burns, A. (2010). Doing Action Research in English Language Teaching: A Guide for Practitioners. New York: Routledge.

Classroom Action Research: The Teacher as Researcher. (1989). Journal of Reading, 33(3), 216-218.

Costello, P. J. M. (2003). Action Research. London: Continuum.

Elyıldırım, S., \& Ashton, S. (2006). Creating Positive Attitudes towards English as a Foreign Language. English Teaching Forum, 44(4), 2-21.

Jones, D., Kaufmann, E., \& Rudd, R. (1990). Daily Classroom Improvement with Action Research. The Agricultural Education Magazine, 76(6), 8-9.

Kieltyka, A. (2005). Exploring the Oral Round Robin Reading Stragey in the Elementary Classroom: An Action Research Study. English Quarterly, 37(4), 10-17.

McCutcheon, G., \& Jung, B. (1990). Alternative Perspectives on Action Research. Theory into Practice, 29(3), 144-151.

Mountford, K. A. (2007). Increase Reading Fluency of 4th and 5th Grade Students with Learning Disabilities Using Readers' Theatre. Saint Xavier University, Chicago.

Nunan, D. (2002). Learner Strategy Training in the Classroom: An Action Research Study. In J. C. Richards \& W. A. Renanda (Eds.), Methodology in Language Teaching: An Anthology of Current Practice (pp. 133-143). Cambridge: Cambridge University Press.

Snell, J. (1999). Improving Teacher-Student Interaction in the EFL Classroom: An Action Research Report. The Internet TESL Journal, 5(4).

Stephens, C., Ascencio, R., Burgos, A. L., Diaz, T., Montenegro, J., \& Valenzuela, C. (2012). Film Circles: Scaffolding Speaking for EFL Students. English Teaching Forum, 50(2), 14-20.

Whitehead, J., \& McNiff, J. (2006). Action Research: Living Theory. London: Sage Publications. 